\title{
COMPLIANCE BEHAVIOR ANALYSIS OF THE SHIP CREW TO THE INTERNATIONAL SAFETY MANAGEMENT (ISM) CODE IN INDONESIA
}

\author{
Desi Albert Mamahit ${ }^{1}$--- Heny K Daryanto ${ }^{2}$--- Ujang Sumarwan ${ }^{3}$--- Eva Zhoriva Yusuf ${ }^{4}$ \\ ${ }_{t, 2,3,4}$ Graduate Program of Management and Business, Bogor Agricultural University, Indonesia
}

\begin{abstract}
The purpose of this code is to provide international standards for the management and safe operation of ships and pollution prevention Furthermore, this study has the objective to identify the role of the ISM Code on maritime activities in Indonesia, knowing the perceptions and attitudes regarding the conduct of the crew boat ISM Code. Location research is conducted on the crew that was in the Port of Tanjung Priok in Jakarta. Data collection and processing is done for 3 months. The study was conducted using a survey approach by distributing questionnaires to the crew (respondents) from different hierarchy. Respondents were asked to fill out questionnaires about the intentions of the respondents in the implementation and compliance with the ISM Code safety rules for shipping. The primary data used in this study were obtained by a structured interview to the crew of passenger ships carrying commodities and goods in the country. Selection of boats done by purposive method, which is the selected ship types ship transporting passengers and goods in the domestic commodities. While the selection is done by the crew convenience method which is one form of non-random sampling methods or non-probabilistic unrestricted. The selection of the crew carried out when the ship was leaning / docked in the port of Tanjung Priok Jakarta and Merak port in Banten. Based on these results it can be concluded in general that the respondents are interested in the concept of the ISM Code as ineffectively to be more related to the supervision of the safety of shipping. It is turns out to be a featured subject of their compliance with the ISM Code as well as the application of this rule is also easy to understand. However, not all respondents are interested in the ISM Code, this is because the respondents consider that the ISM Code executed is just a formality and then it is not supported by the safety adequate equipment, non-compliance crew also based on the lack of socialization of the ISM Code.
\end{abstract}

Keywords: International safety management code, Compliance behavior, Perception 


\section{INTRODUCTION}

\section{Background}

Theory of planned behavior is an extension of the theory of reason action, the theory of reasoned action was first coined by Ajzen in 1980. The theory of reasoned action developed using the basic assumption that people behave in a way that consciously and consider all available information. Ajzen argued that the intention to do or not do certain behaviors are influenced by two basic determinants, the first dealing with the attitude (attitude towards behavior) and the other related to the norms of social influence opinion (subjective norms). In contrast to the theory of reasoned action, the theory of planned behavior Ajzen added a variable construct that does not exist in the theory of reasoned action that control the behavior (perceived behavioral control). Just as the theory of reasoned action, a major factor in the theory of planned behavior is intention (intention) to indicate a given behavior. Intention is assumed to stimulate the motivational factors that influence behavior. It can be shown through one's effort to try, plan and showed behavior. In addition to the motivation, behavior is also influenced by non-motivational factors such as the fulfillment of resources and opportunities can be time, money, expertise, and cooperation with others (Ajzen, 1991). In practice the theory of planned behavior is needed to study the attitudes and behavior in areas such as marketing, health, education, politics and so forth. One is in terms of compliance. International Safety Management (ISM) Code is one of the rules that concern important enough by audiences the world, especially the world voyage. This regulation was developed since July 1, 1998 by the International Maritime Organization (IMO) as a reaction to the increase in the number of accidents and claims the shipping and insurance industries are the subject of international attention. The purpose of these rules is to provide an international standard for managing and operating safe ships and pollution prevention. Based on the fact some passenger vessel accidents during 2003 to 2011 proved that the safety of the ship of governance is still weak. At least there were 30 boating accident during the period 2003 to 2011 in Indonesia such as collision, fire, explosion, sinking and overturned.

\section{Objective}

This dissertation aims to understand the shift in attitude towards the implementation of the compliance of the crew of the ISM Code for shipping in Indonesia based on the Theory of Planned Behavior.

\section{LITERATURE REVIEW}

\section{International Safety Management Code (ISM Code)}

International Maritime Organization (IMO) on a periodic basis to discuss issues of international maritime safety has yielded conventions such as the International Safety Management (ISM) Code, 1998 and the International Ship and Port Security (ISPS) Code (www.mappel.org, accessed 
on January 1 2012). International Safety Management (ISM) Code is an international standard of safety management in the operation of the vessel as well as the prevention and control of environmental pollution that regulate the organization of shipping, vessel, and crew. In the ISM Code defined functional requirements for Safety Management System (SMS), such as safety and environmental protection policies, instructions and procedures to ensure the safe operation of ships and protection of the environment in accordance with the laws of the State and international flags apply. It is also defined levels of authority and lines of communication between and amongst shore and ship as well as supporting a number of procedures such as the procedures for reporting accidents and non-conformities with the provisions of this code, the procedure for preparing and responding to emergencies. Procedures for internal audits and management reviews (Bureau Classification Indonesia, 2011), besides, the shipping company should be able to appoint / assign human resources and responsibility to supervise the safety of shipping companies are doing a good job in their respective field of shipping.

\section{Consumer Behavior}

Engel et al. (1994) define consumer behavior as actions directly involved in obtaining, consuming, and spent products and services, including behavioral processes that precede and follow the action. "Understanding consumer behavior is not easy for the consumer to decide certain purchase different and vary greatly in age, income, education level, and appetite. It is the duty of marketers to examine the factors underlying consumers to choose one or more of the range of products offered by the company. Engel et al. (1994) also argues that there are three factors that affect consumer behavior, namely: Environment; consumers live in a complex environment where the behavior of their behavior is influenced by cultural, social class, personal, family and situation. Then individual differences, in this context there are five external factors that drive and influence consumer behavior namely consumer resources, motivation and engagement, knowledge, attitudes, personality, lifestyle, and demographics. Psychological factors are also considered to support the formation of patterns of customer behavior including information processing, learning, and change attitudes and behaviors. Meanwhile, according to Assael cited by Sutisna (2004) describe the factors that influence consumer buying behavior illustrates that consumers are influenced by three main factors. The first factor of individual consumers that to buy a certain brand products are affected by the things that is in the consumer, needs, perceptions of the characteristics of the brand, the attitude, the demographics, lifestyle, and personality characteristics of individuals will influence the individual choice of the various alternatives available. Secondly, environmental factors that affect consumers, that consumer' choices are influenced by the brand environment surrounding them. Therefore social interactions conducted by a person will also influence the brand choices are purchased. And third, the factors that a marketing strategy marketers try to influence consumers by using stimuli-marketing stimuli such as advertising and the like so that consumers are willing to choose the brand. 


\section{METHODOLOGY}

\section{Time and Location}

The research is conducted on the crew that was in the Port of Tanjung Priok Jakarta and Merak Banten. Data collection was carried out for 1 months, while the data processing and analysis as well for 1 (one) months.

\section{Research Approach}

The study was conducted using a survey approach by distributing questionnaires to the crew (respondents) from different hierarchy. Respondents were asked to fill out questionnaires about the intentions of the respondents in the implementation and compliance with the ISM Code safety rules for shipping. While the data sources used in the majority of studies using primary data (interviews and direct observation) collected directly from respondents through a questionnaire.

In this research study will be presented in two models namely Model 1 refers to the model developed by Kim et al. (2007) and Omondi et al. (2010), and model 2 refers to the model developed by Pavlou and Chai (2002). Both models developed the theory of planned behavior proposed by Ajzen (1991), supported by confidence factor of trust.

\section{Sampling}

The primary data used in this study were obtained by a structured interview to the crew of passenger ships carrying commodities and goods in the country. Selection of boats done by purposive method, which is the selected ship types ship transporting passengers and goods in the domestic commodities. While the selection is done by the crew konvenien method which is one form of non-random sampling methods or non probabilistic unrestricted. The selection of the crew carried out when the ship was leaning/docked in the port of Tanjung Priok Jakarta and Merak Banten. In addition, the use of secondary data obtained by the method of documentation or direct quotes from various sources through library research (library research) and examined by studying literature in the form of books, journals, or papers.

\section{Descriptive Analysis}

In data processing, a descriptive analysis is intended to transform the raw data set into a more concise information that is easy to understand. Thus, the purpose of the analysis is descriptive is to simplify the data into a form that is more easily read and interpreted. Descriptive analysis consists of two stages. The first stage is to tabulate data on the respondents, and the second stage is to interpret the data from the tabulation. The descriptive analysis in this study is used to simplify the demographic data, perceptions and behavioral intentions of respondents. 


\section{Data Processing and Analysis Techniques}

\section{Descriptive analysis}

In data processing, a descriptive analysis is intended to transform the raw data set into a more concise information that is easy to understand. Thus, the purpose of the analysis is descriptive is to simplify the data into a form that is more easily read and interpreted.

\section{Structural Equation Modeling (SEM)}

SEM is a combination of factor analysis and path analysis. SEM is usually used in the field of social psychology.

\section{Reliability Test}

Reliability is a measure of the internal consistency of the indicators of a construct. Reliability was tested by construct reliability and variance extracted. Construct reliability and variance extracted is calculated by the following formula:

$$
\begin{aligned}
& \text { Construct Reliabilit y }=\frac{\left(\sum \text { standardiz e loading }\right)^{2}}{\left(\sum \text { standardiz e loading }\right)^{2}+\sum g j} \\
& \text { Variance Extracted }=\frac{\left(\sum \text { standardiz e loading }{ }^{2}\right)}{\left.\sum \text { standardiz e loading }{ }^{2}\right)+\sum g j}
\end{aligned}
$$

While it can be calculated with the formula $\varepsilon j$ $\varepsilon j=1-[$ standardize loading $]$. In general, the value of acceptable construct reliability was $\geq 0.7$ and $\geq 0.5$ variance extracted (Hair et al., 1998).

\section{ANALYSIS}

\section{Sampling Distribution}

The study was conducted from 6 October 2012 to 9 November 2012 through a survey with interview techniques directly to the crew. The average number of respondents was obtained by 26 respondents per day. This amount adjusts the amount and large vessels surveyed. The number of respondents per vessel ranges from 15 respondents per vessel. Types of ships surveyed consisting of cargo ships and passenger ships. Most of the ships are cargo ships surveyed except KM Labobar, KMP Jatra I, KMP Jatra Jatra II and III, which is a passenger ship. The Average gross weight of cargo ships ranging from 5 to 6 thousand tons. While the gross weight passenger ship is quite diverse, KM Labobar has a gross weight of 15 thousand tons and KMP Jatra I, II and III have a gross weight of three thousand tons. Sailors who participated in the KM Labobar also quite a lot of the 59 respondents while the sailors who participated in KMP Jatra I to III respectively a number between 10 and 14 respondents per ship. This study supported by six companies participating in the research process. The number of respondents involved is as much 
as 206 respondents. Among these companies, PT Tempuran Mas is a company that provides the most number of respondents by 69 respondents. The company provides as much as 5 ships with a gross weight of the vessel between 5 to 6 thousand tons per vessel.

Table-1. Distribution of Respondents by Company and Ship

\begin{tabular}{|c|c|c|c|c|c|}
\hline Company Name & Ship Name & Gross Tonnage & $\%$ & $\begin{array}{l}\text { Total } \\
\text { Respondent }\end{array}$ & Total \\
\hline PT Admiral Lines & KM Amarta Jaya I & 5,477 & $4.9 \%$ & 10 & 10 \\
\hline \multirow{3}{*}{ PT ASDP (Persero) } & KMP Jatra I & 3,871 & $3.9 \%$ & 8 & 33 \\
\hline & KMP Jatra II & 3,902 & $6.8 \%$ & 14 & \\
\hline & KMP Jatra III & 3,123 & $5.3 \%$ & 11 & \\
\hline PT Pelni & KM Labobar & 15,135 & $28.6 \%$ & 59 & 59 \\
\hline PT Samudera Indonesia & KM Sinar Subang & 18,321 & $4.9 \%$ & 10 & 10 \\
\hline \multirow[t]{2}{*}{ PT Tanto } & KM Tanto Kurnia II & 10,359 & $6.3 \%$ & 13 & 25 \\
\hline & KM Tanto Setia & 17,673 & $5.8 \%$ & 12 & \\
\hline \multirow[t]{5}{*}{ PT Tempuran Mas } & KM Jales Mas & 6,499 & $5.3 \%$ & 11 & 69 \\
\hline & KM Kali Mas & 6,603 & $6.8 \%$ & 14 & \\
\hline & KM Mare Mas & 6,603 & $4.9 \%$ & 10 & \\
\hline & KM Strait Mas & 18,355 & $6.8 \%$ & 14 & \\
\hline & KM Sungai Mas & 6,999 & $9.7 \%$ & 20 & \\
\hline Grand Total & & & & 206 & 206 \\
\hline
\end{tabular}

\section{Respondent Characteristics}

Based on this research, some respondents still relatively young, there are at least $21 \%$ of respondents were in the age range between 20 to 25 years. Some $16 \%$ of respondents were in the age range between 41 and 45 years and another $14 \%$ of respondents were in the age range between 31 and 35 years. At the age distribution is also seen seamen who already have more than 55 years of age $(3 \%)$ and there is a small portion under the age of 20 years $(<1 \%)$.

Table-2. Distribution of Respondents by Age

\begin{tabular}{lll}
\hline Age band & $\%$ & Total Respondent \\
\hline$<20$ years & $0 \%$ & 1 \\
$20-25$ years & $21 \%$ & 43 \\
26 - 30 years & $9 \%$ & 18 \\
31 - 35 years & $14 \%$ & 29 \\
36 - 40 years & $20 \%$ & 41 \\
41 - 45 years & $16 \%$ & 33 \\
$46-50$ years & $12 \%$ & 25 \\
51 - 55 years & $4 \%$ & 9 \\
$>55$ years & $3 \%$ & 6 \\
Did not & & \\
answered & $0 \%$ & 1 \\
\hline Grand Total & & 206 \\
\hline
\end{tabular}

Based on the level of education, about half of the respondents graduated to senior high school $(50 \%)$ where the amount is quite high. $25 \%$ of respondents were graduated until academy. Respondents who have completed their education up to bachelor degree is only around $11 \%$. While the rest of the education below senior high school. 
Table-3. Distribution of Respondents by Education Level

\begin{tabular}{lll}
\hline & $\%$ & Total Respondent \\
\hline Junior high school (not finished) & $1 \%$ & 3 \\
Junior high school (finished) & $5 \%$ & 11 \\
Senior high school (not finished) & $4 \%$ & 8 \\
Senior high school (finished) & $50 \%$ & 104 \\
Academy (not finished) & $2 \%$ & 5 \\
Academy (finished) & $25 \%$ & 51 \\
Bachelor (not finished) & $0 \%$ & 1 \\
Bachelor (finished) & $8 \%$ & 17 \\
Post graduate & $2 \%$ & 4 \\
Did not answered & $1 \%$ & 2 \\
\hline
\end{tabular}

The length of work experience of respondents seem to be able to support the understanding of the regulations in shipping, based on the results of the study more than most of the respondents seem to have experience of working on the ship for more than 5 years. A total of $53 \%$ of respondents are in the group. While most of the respondents who are relatively new to the experience in operating vessels less than 6 months there were 32 respondents $(16 \%)$. While respondents who have experience between 6 months to 1 year there were 21 respondents $(10 \%)$, respondents with experience of between 1 to 2 years there were 27 respondents (13\%) and between 2 to 5 years there were 15 respondents (7\%). This indicates that most of the respondents had experienced in operating the ship.

Table-4. Distribution of Respondents by Experience A Ship

\begin{tabular}{lll}
\hline & $\%$ & Total Respondent \\
\hline Less than 6 month & $16 \%$ & 32 \\
Between 6 to 1 year & $10 \%$ & 21 \\
1 - 2 years & $13 \%$ & 27 \\
2 - 5 years & $7 \%$ & 15 \\
Above 5 years & $53 \%$ & 110 \\
Did not answered & $0 \%$ & 1 \\
\hline Grand Total & \multicolumn{2}{|c}{206} \\
\hline
\end{tabular}

\section{Behavioral Compliance Analysis In Running ISM Code}

At the time of seafarers since the first occasion on shipping safety regulations, most of them understand it as safety (32\%). This shows that the rules on the safety of shipping is considered as the rules relating to the subject of safety. At the same time other respondents considering shipping safety rules as regulations to prevent accidents (17\%), respondents also linked the rules with safety equipment $(16 \%)$ and most of the other respondents mengkonotasikannya as a rule $(13 \%)$. 
Table-5. Top of Mind of Safety Regulations

\begin{tabular}{lll}
\hline Top of Mind & $\%$ & Total Respondent \\
\hline Safety & $32 \%$ & 66 \\
Prevent accident & $17 \%$ & 36 \\
Safety equipment & $16 \%$ & 32 \\
Rule & $13 \%$ & 27 \\
Did not answered & $7 \%$ & 14 \\
Compliance & $4 \%$ & 9 \\
Doing the good work & $4 \%$ & 8 \\
Knowledge on Safety & $2 \%$ & 5 \\
Accident & $2 \%$ & 5 \\
Safety exercise & $1 \%$ & 2 \\
Ship & $0 \%$ & 1 \\
Error & $0 \%$ & 1 \\
\hline Grand Total & & 206 \\
\hline
\end{tabular}

While it is remembered on the second occasion still safety (22\%), the next is to prevent accidents $(20 \%)$, safety equipment $(16 \%)$ and rules $(11 \%)$. So it can be concluded that at least $54 \%$ of respondents considering shipping safety rules as rules related to safety well considering the first or second occasion. And $37 \%$ of respondents linking shipping safety regulations with accident prevention efforts. As well as $32 \%$ of respondents linking them with safety equipment.

Table-6. Remembered on The Second Occasion of Safety Regulations

\begin{tabular}{lll}
\hline Unaided & $\%$ & Total Respondent \\
\hline Safety & $22 \%$ & 46 \\
Prevent accident & $20 \%$ & 41 \\
Did not answered & $18 \%$ & 38 \\
Safety equipment & $16 \%$ & 33 \\
Rule & $11 \%$ & 23 \\
Safety knowledge & $4 \%$ & 8 \\
Accident & $3 \%$ & 6 \\
Compliance & $2 \%$ & 4 \\
Good of work & $2 \%$ & 4 \\
Human resources & $1 \%$ & 3 \\
\hline Grand Total & & 206 \\
\hline
\end{tabular}

The study also sought to reintroduce the concept of the ISM Code to the respondents. In the process of the introduction of the respondents are interested or not interested in the concept of the ISM Code itself. So that there are approximately $94 \%$ of respondents think the concept interested ISM Code. ISM Code related concepts are only one of the respondents were not interested. And about 10 respondents (5\%) who answered the ordinary. Respondent which felt interested by the ISM Code governing safety (54\%)? A similar argument is also displayed on the respondents said it was very interesting (58\%). Safety shows two meanings, namely safety as it 
has always been associated with the ISM Code rules, and possibly others are great expectations for the ISM Code in maintaining the safety of sailors when sailing.

Table-7. The ISM Code Concepts Interest

\begin{tabular}{lll}
\hline & $\%$ & Total Respondent \\
\hline Very interested & $50 \%$ & 102 \\
Interested & $44 \%$ & 91 \\
Ordinary & $5 \%$ & 10 \\
Not interested & $0 \%$ & 1 \\
Did not & & \\
answered & $1 \%$ & 2 \\
\hline Grand Total & & 206 \\
\hline
\end{tabular}

In addition to safety related, they suggest that the ISM Code provides insurance against accident prevention, and the ISM Code is the rules that support their work, and the ISM Code are rules that provide knowledge about the safety and the rules are easy to understand. Unlike ordinary respondents said, some of these respondents gave mixed reviews. Respondent argues that the ISM Code is difficult to understand (10\%) and interfere with their job (10\%), although most of the other respondents said that the ISM Code are safety rules (40\%). The interesting thing when looking at respondents' opinions that say not interested, respondents said that the implementation of the ISM Code had been running just as a formality.

Table-8. Responding Reasons Toward ISM Code Concept

\begin{tabular}{|c|c|c|c|c|}
\hline & Reasons & $\%$ & Total Respondent & Total \\
\hline \multirow[t]{10}{*}{ Very interested } & Rule of safety & $58 \%$ & 59 & 102 \\
\hline & Prevent accident & $13 \%$ & 13 & \\
\hline & Support the work & $10 \%$ & 10 & \\
\hline & Safety knowledge & $10 \%$ & 10 & \\
\hline & Did not answered & $3 \%$ & 3 & \\
\hline & The rule that easy to understand & $3 \%$ & 3 & \\
\hline & Rule of law & $1 \%$ & 1 & \\
\hline & The rule that required & $1 \%$ & 1 & \\
\hline & Safety equipment & $1 \%$ & 1 & \\
\hline & Security & $1 \%$ & 1 & \\
\hline \multirow[t]{8}{*}{ Interested } & Rule of safety & $54 \%$ & 49 & 91 \\
\hline & Safety knowledge & $18 \%$ & 16 & \\
\hline & Prevent accident & $15 \%$ & 14 & \\
\hline & Did not answered & $7 \%$ & 6 & \\
\hline & The rule that easy to understand & $2 \%$ & 2 & \\
\hline & Support the work & $2 \%$ & 2 & \\
\hline & Safety equipment & $1 \%$ & 1 & \\
\hline & Ship services & $1 \%$ & 1 & \\
\hline \multirow[t]{7}{*}{ Ordinary } & Rule of safety & $40 \%$ & 4 & 10 \\
\hline & Difficult to understand & $10 \%$ & 1 & \\
\hline & Disturb the work & $10 \%$ & 1 & \\
\hline & Safety & $10 \%$ & 1 & \\
\hline & Did not answered & $10 \%$ & 1 & \\
\hline & Prevent accident & $10 \%$ & 1 & \\
\hline & Support the work & $10 \%$ & 1 & \\
\hline Not interested & Just a formality & $100 \%$ & 1 & 1 \\
\hline \multirow[t]{2}{*}{ Did not answered } & The rule that easy to understand & $50 \%$ & 1 & 2 \\
\hline & Rule of safety & $50 \%$ & 1 & \\
\hline Grand Total & & & 206 & \\
\hline
\end{tabular}


Regarding the advantages possessed by the ISM Code, the respondents consider the ISM Code safety rules that manage both vessels and passengers (26\%). Again, safety is the main brand of the ISM Code minds of sailors. Respondents also argue that the ISM Code is a rule that a reference to other rules or procedures (16\%). This indicates that the ISM Code is positioned by the respondents as the main rules compared to other rules. Respondent also considered the ISM Code is easy to understand (15\%), and the ISM Code is a rule that can prevent ship accidents (13\%), and as a rule they think is better $(12 \%)$. While the ISM Code deficiencies, respondents tend to not want to respond.

Table-9. ISM Code Advantages Compared Other Regulations

\begin{tabular}{lll}
\hline & $\%$ & Total respondent \\
\hline Rule of safety & $26 \%$ & 53 \\
Rule references & $16 \%$ & 33 \\
The rule that easy to understand & $15 \%$ & 31 \\
Prevent accident & $13 \%$ & 27 \\
Did not answered & $12 \%$ & 25 \\
Better rule & $12 \%$ & 25 \\
Support the work & $2 \%$ & 4 \\
A clear rule & $1 \%$ & 3 \\
Different rule & $1 \%$ & 2 \\
Make a work comfort & $0 \%$ & 1 \\
Knowledge of safety & $0 \%$ & 1 \\
Ship management & $0 \%$ & 1 \\
\hline Grand Total & & 206 \\
\hline
\end{tabular}

Respondents also explained that the place they used to study the ISM is a company where the respondent worked $(78 \%)$. Besides magazines, books or other print media (12\%) to other media. And $6 \%$ were studying the ISM Code through the internet, in practice proved that the ISM Code is less a major concern, it appears about $67 \%$ of respondents read the ISM Code last time was more than 1 month ago ( $46 \%$ over 3 months, 13\% three months ago and $8 \% 2$ months ago). Only about $31 \%$ of respondents who read the ISM Code in the past month (18\% one month ago and $13 \%$ two weeks ago), and the rest did not answer (2\%). For the respondents who responded about the ISM deficiencies, the ISM Code is considered not effectively regulating ship safety and pollution (4\%), while respondents said that it appeared the tools inadequate safety (4\%), they also found that difficult to implement the ISM Code (3\%), in the opinion of the other respondents felt the ISM Code is not well socialized (3\%) and human factors are considered as a factor determining the safety of shipping $(2 \%)$.

In practice proved that the ISM Code is less a major concern, it appears about $67 \%$ of respondents read the ISM Code was more than 1 month ago (46\% over 3 months, $13 \%$ three months ago and $8 \% 2$ months ago). Only about $31 \%$ of respondents who read the ISM Code in the past month ( $18 \%$ one month ago and $13 \%$ two weeks ago), and the rest did not answer (2\%). 
Table-10. ISM Code Deficiencies Compared Other Regulations

\begin{tabular}{lcc}
\hline & $\%$ & Total respondent \\
\hline Did not answered & $71 \%$ & 146 \\
Not effective & $4 \%$ & 9 \\
Inadequate safety equipment & $4 \%$ & 8 \\
Difficult to implement & $3 \%$ & 7 \\
Not socialized & $3 \%$ & 6 \\
Human factor & $2 \%$ & 3 \\
Unfamiliar & $1 \%$ & 3 \\
Neglect to implement & $1 \%$ & 2 \\
Need to review and revise & $1 \%$ & 2 \\
Not understand & $1 \%$ & 4 \\
Not executed & $2 \%$ & 2 \\
Nor proven to ensure the safetiness & $1 \%$ & 2 \\
Not complete & $1 \%$ & 1 \\
New rule & $0 \%$ & 1 \\
Less training & $0 \%$ & 1 \\
No punishment & $0 \%$ & 1 \\
The language is difficult to understand & $0 \%$ & 1 \\
Difficult to understand & $0 \%$ & 1 \\
No attention from government & $0 \%$ & 1 \\
No synchronize management & $0 \%$ & \\
\hline Grand Total & & 206 \\
\hline
\end{tabular}

Table-11. Last Read the ISM Code

\begin{tabular}{lll}
\hline & $\%$ & Total Respondent \\
\hline Above 3 month & $46 \%$ & 95 \\
Last 3 month & $13 \%$ & 27 \\
Last 2 month & $8 \%$ & 16 \\
Last 1 month & $18 \%$ & 37 \\
Last 2 week & $13 \%$ & 27 \\
Did not & & \\
answered & $2 \%$ & 4 \\
\hline Grand Total & & 206 \\
\hline
\end{tabular}

Other findings, namely, that seems most respondents believed that the ISM Code is not implemented by elements that work on the ship. This is evident from the recognition of approximately $15 \%$ although $74 \%$ of respondents said that all the other elements on the ship had been carrying out ISM Code. And $11 \%$ of them feel no idea. Willingness to implement the ISM Code was not fully constructed by the individual conscience of each sailor, there are at least $5 \%$ of the respondents who answered less willing and very unwilling, and $3 \%$ of respondents who answered between willing and unwilling. Despite the majority of respondents said it is willing (61\%) and very willing (31\%). 
Figure-1. Implementation of the ISM Code By All Elements Vessel

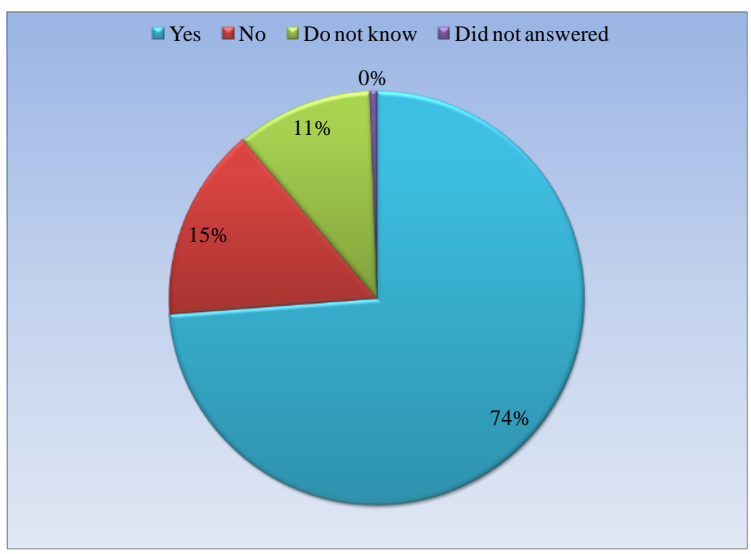

\section{Perception Analysis of the ISM Code}

This study seeks to explore the perceptions held by respondents as a seaman with the sensory experience they had while working on the boat to safety rules and prevention of environmental pollution ISM Code. Each perception is given a score of 1 to 5, which reflects opinion between strongly disagree to strongly agree. Based on the results of interviews with respondents perception gained 8 who score above 4 . This suggests that the average respondent's answer in response to those perceptions are between agree and strongly agree. Based on respondents' perceptions of the ISM Code, ISM Code reflects the rule that effectively reduces the risk of an accident (4:48). ISM Code also creates security of shipping (4.38). Respondents found the ISM Code to get support from the government (4.27). ISM Code as well as the rules agreed by all parties (4.20). Respondents also perceived that the ISM Code is a rule implemented correctly and consistently (4.15).

Table-12. Top 5 of ISM Code Perceptions

\begin{tabular}{ll}
\hline Perceptions & Skor \\
\hline Effective in reducing the risk of accidents & 4.48 \\
Creating the security of shipping & 4.38 \\
Government support & 4.27 \\
All parties agreed rules & 4.20 \\
The rules are correct and consistent implementation & 4.15 \\
\hline
\end{tabular}

\section{CONCLUSION AND SUGGESTION}

\section{Conclusion}

Based on these results it can be concluded that in general the respondents are interested in the concept of the rules of the ISM Code as ineffectively to be more related to the supervision of the safety of shipping this turns out to be a featured subject of their compliance with the ISM Code as well as the application of this rule is also easy to understand. However, not all respondents interested in the ISM Code, It is based because the respondents consider the ISM Code executed 
just a formality, and then the implementation of the ISM code is not supported by the safety equipment is not adequate. Noncompliance sailors also based on a lack of socialization ISM Code.

\section{Suggestion}

It needs a more intensive socialization to the crew and further scrutiny by the authorities concerning the safety assurance regulations ISM Code. Besides, the provision of adequate safety equipment in shipping activities are very necessary so that the implementation of the ISM Code is no longer as valuable regulatory formality but actually implemented more effectively so that the rules can easily be adhered to by all parties in the world berkegiatan shipping.

Funding: This study received no specific financial support.

Competing Interests: The authors declare that they have no competing interests.

Contributors/Acknowledgement: All authors contributed equally to the conception and design of the study.

\section{REFERRENCES}

Ajzen, I., 1991. The theory of planned behavior, organizational behavior and human decision processes.

Engel, F. James, Blackwell, D. Roger, Miniard and W. Paul, 1994. Perilaku konsumen, alih bahasa budiyanto. Jakarta: Binarupa Aksara.

Hair, J.F.J., R.E. Anderson, R.L. Tatham and W.C. Black, 1998. Multivariate data analysis. 5th Edn., Upper Saddle River, NJ: Prentice Hall.

Kim, D., L. Donald, H. Ferrin and R. Rao, 2007. A trust-based consumer decisionmaking model in electronic commerce: The role of trust, perceived risk, and their antecedents. Elsevier b. V.

Omondi, D.O., M.K. Walingo, G.M. Mbagaya and L.O.A. Othuon, 2010. Understanding physical activity behavior of type 2 diabetics using the theory of planned behavior and structural equation modeling. International Journal of Social Sciences, 5: 160-167.

Pavlou, P.A. and L. Chai, 2002. What drives electronic commerce across cultures? A crosscultural empirical investigation of the theory of planned behavior. Journal of Electronic Commerce Research, 3(4): 240-253.

Sutisna, 2004. Perilaku konsumen dan komunikasi pemasaran, bandung. Rosda karya.

\section{BIBLIOGRAPHY}

Admiralty dan Maritime Law Guide, 1993. The international safety management code. http://www.admiraltylawguide.com/conven/ismcode1993.html. 
Ajzen, I. and M. Fishbein, 1980. Understanding attitudes and predicting social behavior. Englewood Cliffs, NJ: Prentice-Hall.

BKI, 2011. Kegiatan sertifikasi ism-code. Available from http://www.klasifikasiindonesia.com/ ajax/lain.php?menuku=mpat\&idnya $=422$.

International Association of Marine Aids to Navigation and Lighthouse Authorities, I., 2004. Available from http://site.ialathree.org/.

International Harbour Masters Association., 2002. Port safety - harbour masters address an increasing challenge. Available from http://www.porttechnology.org/journals/ed13/pt13_downloads/pt13_83.pdf.

International Maritime Organization, I., 2004. The safety of life at sea, 1974, and its protocol of 1988: Articles, annexes and certificates.

Komite Nasional Keselamatan Transportasi., 2010. Analisis data kecelakaan dan investigasi transportasi laut tahun 2007-2010. Available from http://www.dephub.go.id/knkt/ntsc_maritime/Laut/Publications/Media\%20Release\%2 oLaut\%202010.pdf. 